\title{
LENGTH-WEIGHT RELATIONS OF EIGHT FISH SPECIES FROM A SMALL CARIBBEAN COASTAL LAGOON, MEXICO
}

\author{
Roberto C. BARRIENTOS-MEDINA ${ }^{1 *}$, Silvia AVILÉS-TORRES ${ }^{2}$, \\ and Jorge A. NAVARRO-ALBERTO ${ }^{1}$
}

${ }^{1}$ Departamento de Ecología, Cuerpo Académico de Ecología Tropical.

Facultad de Medicina Veterinaria y Zootecnia, Campus de Ciencias Biológicas y Agropecuarias,

Universidad Autónoma de Yucatán, Mérida, Yucatán, México

${ }^{2}$ Departamento de Análisis Ambiental, Secretaría de Protección al Ambiente,

Gobierno del Estado de Baja California, Ensenada, Baja California, México

Barrientos-Medina R.C., Avilés-Torres S., Navarro-Alberto J.A. 2013. Length-weight relations of eight fish species from a small Caribbean coastal lagoon, Mexico. Acta Ichthyol. Piscat. 43 (1): 71-74.

\begin{abstract}
Due to the importance of the estuarine fish fauna in Mexico and the implications of length-weight relation (LWR) for management and conservation, we present the estimates of the LWR for eight fish species from Rio Huach, a small estuarine system of the Mexican Caribbean. Fishes were caught in five sampling points during an annual cycle (1998) and in November of 2000, were measured with a digital calliper and weighed with a digital balance to obtain the standard length (SL) and weight $(W)$. The LWR were obtained with two estimation methods: standardized major axis (SMA) and ordinary least squares (OLS). A total of 678 specimens were suitable for analysis. The estimates of LWR for Bathygobius soporator (Valenciennes, 1837) and Cyprinodon artifrons Hubbs, 1936 are presented here for first time, and for four species statistical differences with previous estimations of LWR were found (considering one or both estimation methods). With these results, the knowledge of LWR for tropical fish species is increasing and the importance of considering the estimation of LWR parameters using the standardized major axis method is discussed.
\end{abstract}

Keywords: Estuarine fishes, length-weight relations, regression methods, Mexican Caribbean

Coastal lagoons of Mexico are inhabited by a wide variety of organisms including fish. The latter are important not only for their diversity and the numbers but also for their ecological role in this type of environments (Castro-Aguirre et al. 1999). Despite the importance of estuarine fish fauna of Mexico and the implications of the knowledge of the length-weight relation (LWR) in areas related to the management and conservation of fish species (Froese 2006, Froese et al. 2011), the information available to the Mexican species is still limited (Gonzalez et al. 2004, Velázquez-Velázquez et al. 2009, De La Cruz Agüero et al. 2011, Vega-Cendejas et al. 2012).

In this paper we present the LWR for eight selected species in Rio Huach, a small estuarine lagoon system of southern Quintana Roo (Mexico), bordered to the east by the Caribbean Sea and to the west by the Bay of Chetumal. Its permanent channel, $1.5 \mathrm{~km}$ long, connects the lagoon with the Caribbean Sea between $18^{\circ} 24^{\prime} 07^{\prime \prime} \mathrm{N}$ and $87^{\circ} 46^{\prime} 41^{\prime \prime} \mathrm{W}$. The approximate area of the lagoon is
$148058 \mathrm{~m}^{2}$ and the only freshwater supply system is through rainfall (Avilés-Torres unpublished ${ }^{* *}$ ).

Eight fish species were selected for this study: Hardhead silverside, Atherinomorus stipes (Müller et Troschel, 1848); frillfin goby, Bathygobius soporator (Valenciennes, 1837); Yucatan pupfish, Cyprinodon artifrons Hubbs, 1936; silver mojarra, Eucinostomus argenteus Baird and Girard, 1855; slender mojarra, Eucinostomus jonesii (Günther, 1879); ocellated killifish, Floridichthys polyommus Hubbs, 1936; redear herring, Harengula humeralis (Cuvier, 1829); scaled herring, Harengula jaguana Poey, 1865. The fish were collected during an annual cycle (1998), but the months of October and November of 2000 were also included. Five fixed sampling points along the lagoon system were considered and fish were sampled with the help of a beach seine $(20 \mathrm{~m}$ long, 1.5-m drop, and 1-cm mesh) and a cast net ( $3 \mathrm{~m}$ in diameter, one high and $25-\mathrm{mm}$ mesh). The fish collected were fixed with $10 \%$ formalin (neutralized with local water) for their later transfer to the laboratory.

\footnotetext{
* Correspondence: M.Sc. Roberto C. Barrientos-Medina. Facultad de Medicina Veterinaria y Zootecnia, Campus de Ciencias Biológicas y Agropecuarias, Universidad Autónoma de Yucatán. Mérida, Yucatán, México. Km. 15.5 Carretera Mérida-Xmatkuil. Apartado Postal 4-116, Código Postal 97100, Itzimná. Mérida, Yucatán, México. Phone and fax: (+52) 999-9423206,email: rcarlos@uady.mx [jorge.navarro@uady.mx, saviles@baja.gob.mx].

** Avilés-Torres S. 2002. Influencia de la heterogeneidad espacial y la fluctuación climática en la comunidad de peces del sistema lagunar Rio Huach, sur de Quintana Roo, México. Tesis de Maestría. Centro de Investigación Científica y de Educación Superior de Ensenada (CICESE), Ensenada, México.
} 
For each individual fish, the size (standard length, SL) was recorded with a digital calliper to the nearest 0.01 $\mathrm{mm}$, while the weight $(W)$ was measured using a $0.01-\mathrm{g}$ precision electronic balance. The LWR was estimated according to recommendations given by Froese (2006) and Froese et al. (2011). Only species represented by more than 30 individuals in the total sample were considered in the analyses.

In order to estimate the regression parameters, first the two variables: SL $[\mathrm{cm}]$ and $W[\mathrm{~g}]$ were transformed to logarithmic scale (base 10) and the presence of influential points (outliers) was detected through inspection of the corresponding scatter plot, which allowed to exclude these values from subsequent analysis.

The estimation of the regression parameters for the line of best fit was performed through the standardized major axis (SMA) method, rather than ordinary least squares (OLS), for the following reasons: the measured fish comprise a random sample, instead of a representative one of the size range of the included species; both variables (SL and $W$ ) are subject to natural variation and/or measurement error, which means that SL is not under the control of the observer; the purpose of the regression is to estimate the parameters of the structural relation between SL and $W$, rather than predicting $W$ from SL and the slope $(b)$ is used to interpret patterns of change in $W$ with changes in SL (Laws and Archie 1981, Warton et al. 2006, Smith 2009).

Calculations of the slope $(b)$, the intercept $(a)$ and their 95\% confidence limits, were performed using the program PAST version 2.17 (Hammer et al. 2001), using bootstrapping in the case of SMA.

A total of 678 specimens (all juveniles), comprising eight species, representing five families, were suitable for analysis. Tables 1 and 2 provides information on sample sizes, the coefficient of determination as a measure of goodness of fit, the regression parameters and their 95\% confidence intervals. In this work, the LWR was obtained in an unconventional way: first, we used a model II regression method (SMA) to estimate the parameters of the line of best fit; second, $95 \%$ bootstrapped confidence intervals were used to estimate the slope and the intercept. However, the estimates obtained with ordinary least squares were also included to facilitate comparison with previous estimations.

Length-weight regressions were significant in all cases $(P<0.001)$, with a goodness of fit between $81 \%$ and $98 \%$. For two species (Cyprinodon artifrons, Bathygobius soporator) the parameters of the LWR are presented for first time (Table 2). For four species (Atherinomorus stipes, Eucinostomus jonesii, Floridichthys polyommus, and Harengula humeralis) the coefficient $b$ was statistically different from 3.0 , considering both estimation methods, thus indicating an allometric relation between $W$ and SL.

The cases of $A$. stipes and $E$. jonesii stand out in the presently reported study, because their corresponding $95 \%$ confidence intervals of parameter $b$ enclose higher

Table 1

Basic information on eight fish species from Rio Huach, Mexico

\begin{tabular}{lccc}
\hline Species & $n$ & $\mathrm{SL}[\mathrm{cm}]$ & $W[\mathrm{~g}]$ \\
\hline Atherinomorus stipes & 246 & $2.1-4.2$ & $0.10-1.50$ \\
Bathygobius soporator & 43 & $2.9-7.2$ & $0.50-6.70$ \\
Cyprinodon artifrons & 52 & $2.4-3.4$ & $0.60-1.90$ \\
Eucinostomus argenteus & 58 & $3.4-9.7$ & $0.60-18.30$ \\
Eucinostomus jonesii & 46 & $2.9-6.1$ & $0.40-4.50$ \\
Floridichthys polyommus & 89 & $2.1-5.1$ & $0.30-4.90$ \\
Harengula humeralis & 112 & $3.7-4.5$ & $0.70-1.60$ \\
\hline
\end{tabular}

$n=$ sample size, $\mathrm{SL}=$ standard length, $W=$ weight.

values in comparison to those found in scientific literature and electronic databases (De La Cruz-Agüero et al. 2011, Froese and Pauly 2012). The differences indicated here could be related to ontogenetic changes in the LWR for these species, since we used only juvenile specimens in the analysis.

For H. humeralis we found statistical differences with previous reports (Froese and Pauly 2012) with the estimates produced by SMA method only, while for $F$. polyommus the estimates provided here are lower than those reported by Vega-Cendejas et al. (2012), although the statistical differences are only appreciated with OLS estimates. In this last case, differences in size, physiological conditions, and other biological and sampling factors between our specimens and those previously reported may explain the discrepancy in the estimates.

As a common practice, OLS method has been used for the estimation of regression parameters in LWR studies (Froese 2006, Froese et al. 2011). However, this method must be applied when the main interests are on the significance of the relation between SL and $W$ ( $P$ - value), the prediction of $W$ from SL values (interpolation) or the goodness of fit (strength) of the linear relation (Warton et al. 2006). Moreover, inference about the parameters produced by OLS estimation method have assumptions that rarely are evaluated in LWR: error term ( $\log$ e) is normally distributed, with mean of zero and a constant variance; the distribution of $\log W$ is normal at each value of $\log \mathrm{SL}$; the variance of $\log W$ is constant across the range of log SL values and log SL is treated as an independent variable, which means that it has been measured without error (Zar 1968, LaBarbera 1989). In particular, the last point is not the usual case in allometric studies, where the LWR is included.

Therefore we recommend that, although OLS is widely used in LWR, the SMA method should be considered for the estimation of regression parameters, as well as in other allometric studies (Gould 1975, de L. Brooke et al. 1999, Hochcheid et al. 2007). The estimated values produced by OLS method can also be included (only for comparative purposes with previous studies), once their assumptions have been evaluated properly. 
Estimated parameters of length-weight relation (LWR) for eight fish species from Rio Huach, Mexico according to ordinary least squares (OLS) and standardized major axis (SMA) estimation methods

\begin{tabular}{|c|c|c|c|c|c|c|c|c|c|c|}
\hline \multirow{2}{*}{ Species } & \multicolumn{4}{|c|}{ OLS } & \multicolumn{4}{|c|}{ SMA } & \multirow{2}{*}{$r^{2}$} & \multirow{2}{*}{$\mathrm{PE}$} \\
\hline & $a$ & CI [95\%] & $b$ & CI [95\%] & $a$ & CI [95\%] & $b$ & CI [95\%] & & \\
\hline $\begin{array}{l}\text { Atherinomorus } \\
\text { stipes }\end{array}$ & 0.007 & $0.006-0.008$ & 3.697 & $3.544-3.858$ & 0.006 & $0.005-0.007$ & 3.837 & $3.678-3.990$ & 0.928 & $3.049[\mathrm{C}]$ \\
\hline $\begin{array}{l}\text { Bathygobius } \\
\text { soporator }\end{array}$ & 0.025 & $0.021-0.031$ & 3.195 & $2.874-3.004$ & 0.023 & $0.012-0.029$ & 2.913 & $2.764-3.039$ & 0.973 & First time \\
\hline $\begin{array}{l}\text { Cyprinodon } \\
\text { artifrons }\end{array}$ & 0.041 & $0.034-0.051$ & 3.009 & $2.883-3.280$ & 0.037 & $0.030-0.041$ & 3.191 & $2.972-3.381$ & 0.940 & First time \\
\hline \multirow[t]{3}{*}{$\begin{array}{l}\text { Eucinostomus } \\
\text { argenteus }\end{array}$} & 0.015 & $0.011-0.020$ & 3.152 & $2.999-3.344$ & 0.014 & $0.011-0.017$ & 3.207 & $3.077-3.355$ & 0.967 & $3.301[\mathrm{~A}]$ \\
\hline & & & & & & & & & & $3.380[\mathrm{~B}]$ \\
\hline & & & & & & & & & & $2.910-3.196[\mathrm{C}]$ \\
\hline $\begin{array}{l}\text { Eucinostomus } \\
\text { jonesii }\end{array}$ & 0.014 & $0.012-0.018$ & 3.147 & $3.003-3.297$ & 0.014 & $0.011-0.017$ & 3.181 & $3.027-3.342$ & 0.979 & $2.650[\mathrm{~B}, \mathrm{C}]$ \\
\hline $\begin{array}{l}\text { Floridichthys } \\
\text { polyommus }\end{array}$ & 0.029 & $0.026-0.033$ & 3.179 & $3.070-3.287$ & 0.028 & $0.024-0.032$ & 3.223 & $3.103-3.333$ & 0.973 & $3.318[\mathrm{~A}]$ \\
\hline $\begin{array}{l}\text { Harengula } \\
\text { humeralis }\end{array}$ & 0.009 & $0.006-0.014$ & 3.350 & $3.048-3.648$ & 0.005 & $0.004-0.008$ & 3.721 & $3.419-4.031$ & 0.811 & $3.006-3.190[\mathrm{C}]$ \\
\hline \multirow[t]{2}{*}{$\begin{array}{l}\text { Harengula } \\
\text { jaguana }\end{array}$} & 0.011 & $0.006-0.019$ & 3.200 & $2.831-3.583$ & 0.008 & $0.005-0.015$ & 3.410 & $3.040-3.760$ & 0.881 & $3.550[\mathrm{~A}]$ \\
\hline & & & & & & & & & & $3.150-3.280[\mathrm{C}]$ \\
\hline
\end{tabular}

$\mathrm{CI}=$ confidence intervals, $r^{2}=$ coefficient of determination, $\mathrm{PE}=$ previous estimates, $[\mathrm{A}]=$ Vega-Cendejas et al. (2012), from Yucatan Peninsula, [B] = De La Cruz-Agüero et al. (2011), from the Atlantic versant of Mexico, $[\mathrm{C}]=$ Froese and Pauly (2012), from Cuba and several other areas in the Atlantic coast.

\section{ACKNOWLEDGEMENTS}

The data presented and analyzed in this study were gathered during the development of the master's thesis of the second author (SAT), as part of the field activities of the project "Distribution and abundance of reef fish fauna on the southern coast of Quintana Roo" with the support given to Dr. Juan J. Schmitter-Soto (El Colegio de la Frontera Sur, Chetumal Mexico) by CONACYT (reference number: 4198T-9405). The quality of this wok was improved by the comments and suggestions of two anonymous reviewers.

\section{REFERENCES}

Castro-Aguirre J.L., Espinosa Pérez H.S., Schmitter-Soto J.J. 1999. Ictiofauna estuarino-lagunar y vicaria de México. Colección Textos Politécnicos. Serie Biotecłnologías. Limusa Noriega Editores, México, DF.

de L. Brooke M., Hanley S., Laughlin S.B. 1999. The scaling of eye size with body mass in birds. Proceedings of the Royal Society of London, series B: Biological Sciences 266 (1417): 405-412. DOI: 10.1098/rspb.1999.0652

De La Cruz Agüero J., García Rodríguez F.J., Cota Gómez V.M., Chollet Villalpando J.G., Vergara Solana F.J. 2011. Length-weight relations of selected species of the family Gerreidae (Actinopterygii: Perciformes) from the Mexican coast. Acta Ichthyologica et Piscatoria 41 (1): 67-69 DOI: 10.3750/AIP2011.41.1.10

Froese R. 2006. Cube law, condition factor and weight-length relationships: history, meta-analysis and recommendations.
Journal of Applied Ichthyology 22 (4): 241-253. DOI: 10.1111/j.1439-0426.2006.00805.x

Froese R., Pauly D. (eds.) 2012. FishBase. [version 12/2012] http://www.fishbase.org

Froese R., Tsikliras A.C., Stergiou K.I. 2011. Editorial note on weight-length relations of fishes. Acta Icthyologica et Piscatoria 41 (4): 261-263. DOI: 10.3750/AIP2011.41.4.01

González-Acosta A.F., De La Cruz Agüero G., De La Cruz Agüero J. 2004. Length-weight relationships of fish species caught in a mangrove swamp in the Gulf of California (Mexico). Journal of Applied Ichthyology 20 (2): 154-155. DOI: 10.1046/j.1439-0426.2003.00518.x

ould S.J. 1975. On the scaling of tooth size in mammals. American Zoologist 15 (2): 351-362.

Hammer Ø., Harper D.A.T., Ryan P.D. 2001. PAST: paleontological statistics software package for education and data analysis. Palaeontologia Electronica 4 (1): 9 pp. http://palaeo-electronica.org/2001_1/past/issue1_01.htm.

Hochscheid S., McMahon C.R., Bradshaw C.J.A., Maffucci F., Bentivegna F., Hays G.C. 2007. Allometric scaling of lung volume and its consequences for marine turtle diving performance. Comparative Biochemistry and Physiology, Part A: Molecular and Integrative Physiology 148 (2): 360-367. DOI: 10.1016/j.cbpa.2007.05.010

LaBarbera M. 1989. Analyzing body size as a factor in ecology and evolution. Annual Review of Ecology and Systematics 20: 97-117. DOI: 10.1146/annurev. es.20.110189.000525 
Laws E.A., Archie J.W. 1981. Appropriate use of regression analysis in marine biology. Marine Biology 65 (1): 13-16. DOI: $10.1007 / \mathrm{BF} 00397062$

Smith R.J. 2009. Use and misuse of the reduced major axis for linefitting. American Journal of Physical Anthropology 140 (3): 476-486. DOI: 10.1002/ajpa.21090

Vega-Cendejas M.E., de Santillana M.H., Arceo D. 2012. Length-weight relationships for selected fish species from a coastal lagoon influenced by freshwater seeps: Yucatan Peninsula, Mexico. Journal of Applied Ichthyology 28 (1): 140-142. DOI: 10.1111/j.1439-0426.2011.01875.x

Velázquez-Velázquez E., Navarro-Alberto J., DomínguezCisneros S.E., Vega-Cendejas M.E. 2009. Length-weight relationships for 24 fish species in a costal lagoon of the
Mexican South Pacific. Journal of Applied Ichthyology 25 (2): 228-229. DOI: 10.1111/j.1439-0426.2008.01199.x

Warton D.I., Wright I.J., Falster D.S., Westoby M. 2006. Bivariate line-fitting methods for allometry. Biological $\begin{array}{lllll}\text { Reviews } & \mathbf{8 1} & \text { (2): } & 259-291 . & \text { DOI: }\end{array}$ $10.1017 / \mathrm{S} 1464793106007007$

Zar J.H. 1968. Calculation and miscalculation of the allometric equation as model in biological data. BioScience 18 (12): $1118-1120$

Received: 10 September 2012 Accepted: 18 February 2013 Published electronically: 31 March 2013 